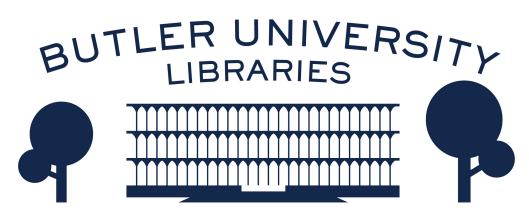

Journal of Hindu-Christian Studies

Volume 7

Article 7

January 1994

\title{
The Dilemma of Diversity and the Boon of Understanding
}

John B. Carman

Follow this and additional works at: https://digitalcommons.butler.edu/jhcs

Part of the Religion Commons

\section{Recommended Citation}

Carman, John B. (1994) "The Dilemma of Diversity and the Boon of Understanding," Journal of HinduChristian Studies: Vol. 7, Article 7.

Available at: https://doi.org/10.7825/2164-6279.1095

The Journal of Hindu-Christian Studies is a publication of the Society for Hindu-Christian Studies. The digital version is made available by Digital Commons @ Butler University. For questions about the Journal or the Society, please contact cbauman@butler.edu. For more information about Digital Commons @ Butler University, please contact digitalscholarship@butler.edu. 


\title{
The Dilemma of Diversity and the Boon of Understanding*
}

\author{
John B. Carman \\ Harvard Divinity School
}

I WANT US to reflect on our religious diversity, and on the increasing religious diversity in North America, which Professor Diana Eck and her team of research students are now documenting and interpreting in the Pluralism Project.

In August [1993] more than 7,000 people from a great variety of religions met in Chicago to celebrate the 100th anniversary of the World Parliament of Religions. That meeting 100 years ago brought the young Hindu reformer Swami Vivekananda to the West - and to Harvard - with the message that for 2500 years India had already accepted a philosophy of religious pluralism, illustrated by an ancient Indian fable that you may know as John Godfrey Saxe's poem "The Blind Men and the Elephant".

Six blind philosophers all investigate the nature of the elephant. One falls against its side and thinks the elephant is like a wall; a second feels the tusk and thinks the elephant is like a spear. For the others, the trunk is like a snake, the leg is like a tree, the ear is like a fan, and finally, "The swinging tail ... Is very like a rope!" The fable refers to the ancient Indian tradition of the "six philosophies". Each religion had its own distinctive list of six opposing viewpoints, but they agreed on one point: all six were wrong, like the six reports about the nature of the elephant.

No ancient religious group interpreting this fable considered its own philosophy to be one of the six alternatives. Early Buddhists, for example, discussed six nonBuddhist "viewpoints", but considered only the Buddha's teaching to be true. While common people often acknowledged the spiritual charisma of competing gurus, and kings felt obliged to support different groups of priests and ascetics, most religious leaders were anything but tolerant of opposing views.

Only a thousand years later did the Indian approach to philosophical and religious alternatives begin to change. I learned of this important shift through the doctoral research of the late Kendall Folkert, whose studies of the Jains, the most ancient Indian religious minority, have been posthumously edited by John Cort and recently published. ${ }^{2}$ Ken Folkert discovered that while the earliest Jain views of other philosophies were just as negative as those of Buddhists and Hindus, Jains later started to compose summaries of six religious systems that included their own, and that were presented without a Jain refutation. Sometimes they interpreted other philosophies as one-sided views that mistakenly treated one perspective on reality as absolute. Jains considered the superiority of their philosophy to be its recognizing a multiplicity of perspectives and its combining those perspectives to gain the most adequate grasp of reality. ${ }^{3}$ For these Jain thinkers the problem was not primarily that the philosophers in the fable were blind,

* Abbreviated Harvard Divinity School 1993 Convocation Address. Reprinted with permission from Harvard Divinity Bulletin 1993, 23, 1: pp.4-6. 
for they gained some real knowledge through their touch, but they drew the wrong conclusions from their partial evidence, and they refused to consider the contrary evidence of their colleagues. Each was sure that he alone was right. This fable is not about physical blindness, but addresses those who are overconfident about their vision of reality.

Gradually the other schools also produced their lists of diverse viewpoints, lists that now included their own position. They did not, however, consider all these points of view equally close to the truth. The South Indian devotees of the god Siva, for example, developed a list of 18 viewpoints, arranged in three concentric circles, with their own doctrine in the highest position in the inner circle.

The ancient interpretation of the fable considered all six philosophies false, in sharp contrast to the true teaching, their own. The medieval interpretation regarded the six philosophies as different perspectives with varying degrees of truth, but only one perspective contained the final truth: namely their own. Modern theories of religious pluralism have taken this theory of diverse perspectives a step further, considering all the perspectives to be at the same level of truth: all religions are equal, including one's own. While the medieval Jain approach acknowledges the different seekers' partial grasp of a real elephant, the superior vantage point of Jain philosophy makes it possible to arrange and rank these different perspectives. In the modern pluralistic interpretation, however, each of the groping seekers is thought to be equally in touch with ultimate reality.

Yet unless at least the storyteller has a clear view of the elephant, how do we know that all the seekers are touching the same reality? How do we know that one blind man is not holding onto a tree trunk, another bumping up against a wall, a third just hugging himself? Traditional interpretations of the story depended on the presence of an enlightened teacher or an awakened community well on its way to the goal of true insight, and often believing in some Divine disclosure of how reality once was and might some day be again. Without an enlightened guide, can any of us, if we cannot yet truly see the truth, really assess the diversity of human opinion and practice? In fact, the modern Hindu philosophy that claims to treat different religions equally also has a superior vantage point, a particular view of the unitive consciousness of ultimate reality, on the basis of which it can affirm the mystical experience of unity by Muslim mystics, Christian mystics, or Buddhist mystics, while subordinating other forms of religion.

Religious diversity poses no dilemma for those who are convinced there is one true path, nor for those comfortable with a modern pluralistic spirituality that claims to give equal status to all earnest seekers after truth. The dilemma arises if we cannot choose between the two opposite interpretations of the ancient fable. "Pluralism" is not just recognizing religious diversity but is one particular theory or "-ism" to make sense of it. Can celebrating pluralism mean more than rejoicing with those who agree with our theory?

We should like to be part of a diverse community in which all have equal voice that is one horn of the dilemma. The other horn is simply this: unless we acknowledge a truth that not everyone else shares, we are in danger both of losing our footing on our particular path and of having no vision of the whole. We may be simply groping in the dark.

At our [Harvard] "Center for the Study of World Religions" we have been concerned with mutual understanding among diverse religious communities and, more specifically, among scholars who want both to learn about other religious traditions and to interpret their own. While interreligious understanding does not solve the theological dilemma of religious diversity, it does have two important functions. First, it is an effort 
to grasp what is different from our own religion, but sufficiently similar to be imagined by analogies from our own experience. Such imagination is not possible without factual knowledge, the learning of another religious language, but interreligious understanding is more than knowing two sets of religious symbols. It is translating back into one's own religious language something that differs from it. Interreligious understanding involves new discoveries about the faith of other people, new recognitions of both similarities to and differences from one's own faith. The second function of such understanding has sometimes been called the "mirror effect". Not only is one's understanding of another person's religion affected by one's own, but eventually, one's understanding of another faith may, in unpredictable ways, change one's own.[...]

The nature of interreligious understanding was the topic of a joint course I taught several times in the 1970s with Professor J.L. Mehta. He came to the Divinity School and the Center after a long career as Professor of Philosophy at Banaras Hindu University. Our course grew out of his effort to explain to me why Indian universities resisted the plan proposed by Wilfred Cantwell Smith to establish departments of comparative religion. Traditional Hindu thinkers, he showed me, had not only a different notion of "religion" but also a different idea of what "understanding" means. Dr Mehta contrasted the typical Western approach to understanding, trying to grasp an object separate from oneself, with the traditional Hindu approach of assimilating the object to be understood until it becomes part of oneself. Dr Mehta was intrigued by the Western objectifying mode of understanding, but he believed that the deepest "understanding" was a traditional Indian union of knowledge, faith and metaphysical realization. My effort to separate my historical understanding from my theological evaluation made him uncomfortable, as he disclosed during his farewell address at the Center in January 1979 before he returned to India:

If I have to find fault with Professor Carman's role in these joint courses, it is that he has been altogether too gentle with me all along ... there is an element of mutual grappling and fight in such dialogues, without which they easily turn into a mere exchange of courtesies. In order to be fruitful, the dialogue must be conceived also as a mutual challenging, a calling out to the other to come out in the open, and it needs being conducted as a "liebende Kampf" to use Karl Jaspers striking phrase. ${ }^{4}$

Dr Mehta went on to speak of his frustration with this modern reticence of many Western Christians to express their deepest convictions, and he contrasted this reticence with the outspoken statements of earlier Western scholars that the purpose of their studies was to uproot the Hindu developments of the last three thousand years, or to convert "the natives of India to the Christian religion", or to provide the necessary basis for maintaining the British Empire in India. Listening to him I had to ask myself whether any of these motives of political or religious imperialism lay concealed behind my effort, as a historian and phenomenologist of religion, to refrain from assessing the truth or value of medieval or modern Hinduism. My postponement of evaluation until I had adequately understood Hindu theology may have given the impression of unconcern about the truth of Hindu teaching, since the postponement just continued indefinitely; the adequate understanding I sought was never quite reached. Still worse, I may have appeared to be hiding my critical judgements behind a mask of courtesy.

I deeply regret that I disappointed my friend by not engaging with him in such a liebende Kampf, a "loving struggle". Perhaps now, five years after Dr Mehta's death during his final visit to Cambridge, I should come "out in the open". To put his 
challenge in different terms, I should seek not only to listen sympathetically to others' views, but also to "speak the truth in love". to express my viewpoint on reality.

I hope that my reticence to speak out is more than a fear of offending you. This past July [1993] I took part in a small working group of the Lutheran World Federation in Madras, a group made up largely of Indian Christians, convened to think through Christian interpretations of Hinduism. I have come home still convinced that Indian Christians themselves must play the major role in developing such an interpretation, but more confident that I, too, can contribute to their discussion, for Christian theology is and ought to be a cooperative enterprise for the whole Church in conversation with the whole world. All of us are groping; we need to try to help one another.

I agree with Dr Mehta on the connection between understanding other religions and deeper understanding of one's own. My growing acquaintance with Hindu worship of sacred images has increased my appreciation of Roman Catholic and Eastern orthodox ritual. My study of Hindu philosophy has shown me divisions parallelling those in Western religions, and I know on which side I stand: I affirm the personal qualities in God's nature, anthropomorphic and paradoxical though they may be. My study of the doctrine of avatära (Divine descent) has led me to see the common Hindu and Christian concern with Divine condescension but also to put more weight on the distinctive Christian emphasis on God's humiliation and self-sacrifice in Jesus.

I want to affirm the moral relevance of our effort at understanding. The English word "understanding" also means the coming to some practical agreement after a relationship of antagonism and misunderstanding. The effort to settle a dispute requires of both sides not only intelligent listening but also intelligible speaking. The dialogue required involves not only understanding the other but witnessing to one's own faith. The practical agreement reached may be small and tentative, but our speaking together may help us to agree on the meaning of some of the words we use, and we may find that there are many things on which we can agree to disagree. There is a rich variety of human tastes, and there is an even greater range of possibilities in human languages. Yet at some point one crosses the line from taste to truth, from gentility to justice, and this is where a pluralistic society is severely tested. Academic understanding does not itself bring us to wise decisions, but we neglect such understanding at our peril. Indeed, the greater the strains of diversity, the more grateful we should be for the opportunity of understanding.

This is why I speak of "the boon of understanding", a phrase I owe to Steven Peterson. [...] In the midst of religious diversity the attainment of understanding is a boon. The effort required brings no automatic results. The understanding we most prize comes to us as a discovery, even as a Divine surprise. That is just as well, for traditional religions, which differ on so many subjects, are in much agreement about the severity of our human ignorance, weakness, and bondage. As human beings we badly need help, and one modest form that help takes is the boon of understanding.

The Indian fable I have told presents the picture of human beings trying to determine by their touch the nature of the elephant. I now want to mention a second Indian simile about the elephant. [...] .

How can a lame person climb on an elephant if you tell him to do so? ... The answer is surely that the elephant can accommodate itself, kneeling down so that the lame person can mount. God likewise makes himself very low so that he can be worshipped by the soul in this imperfect world. ${ }^{5}$

In both similes the elephant represents ultimate reality, and in both its greatness is contrasted with human incapacity. Here, however, the elephant takes an active role in solving the human problem, for the elephant 
kneels down and takes the lame person on its broad back. The elephant represents not only the goal but the means. Here Ultimate Reality descends to the human level to rescue, raise up, and support those who cannot move themselves.

The anecdote gives us no solution to the dilemma of diversity, but it may be seen as one of many recognitions in various religious traditions that the human predicament is insoluble without Divine intervention, without an unmerited and unanticipated Divine gift. The second simile, I realized recently, also casts some light on the first. As I reread the poem I was puzzled by the second verse, which goes as follows:

The First approached the Elephant, And happening to fall

Against his broad and sturdy side, At once began to bawl:

"God bless me but the Elephant Is very like a wall!"6

Why did the first philosopher think the elephant was like a wall? He might have bumped his head against the elephant's underbelly, but why would he have stumbled against its side, unless this elephant was not standing up but kneeling down? All these years I have known the story I have been picturing this elephant standing, and standing still. That is the way the wooden elephants we brought back from India look, but the Indian story is about a live Indian elephant. If you have ever encountered a rogue elephant, as we once did driving through an Indian forest preserve, then you will realize that such a reality calls for only one response - get away fast. The blind philosopher would have been foolhardy to approach any elephant unless that great creature was under the control of its driver, the mahout and - even better - kneeling down. For the philosopher as well as for the devotee, it is essential that the Invisible Reality we seek accommodate itself to our groping touch.

To view understanding itself as a sign of Divine grace is certainly a theological interpretation, an interpretation from the standpoint of my faith in Jesus Christ as God's crucial gift to humanity. I believe that through Jesus God has secretly transformed our world, and through Jesus God will make that transformation manifest in the future. For the present I must be content with occasional signs, signs of God's universal saving process that I have to interpret from my particular perspective, from which I can gratefully affirm that the "wideness in God's mercy" far exceeds the depth of my faith and the clarity of my understanding. My Christian perspective inevitably affects my view of the whole. Working it out systematically would involve me in difficult judgements concerning the partial truth of other viewpoints. For those with other perspectives, however, my systematic theology would appear not as the truth, but as one particular human viewpoint, just as the grand synthesis of modern Hindu philosophy appears to those who do not share that faith in the realization of the soul's infinite ground.

Each of these theological visions of the whole is a kind of pluralism, but is there any "pluralism" in which we can all share? No, I submit, if we expect a fundamental and comprehensive agreement about the nature of reality. Yes, if we are prepared to live and work together with many fragmentary "understandings" - to which, I believe, our academic understanding can contribute. I take the statement on a global ethic, signed by many representatives of many diverse religions at the recent meeting in Chicago, as the beginning of one such process, which may lead not only to some limited theoretical agreement, but to some common action so desperately needed on our common planet.

The fundamental understanding among human beings in which Dr Mehta believed is in practice continually thwarted, but there are breakthroughs, both for individuals and for communities, even in our troubled present. The Biblical passages read (Genesis 11:1-9 and Acts 2:1-13) use the metaphor of 
speech instead of the metaphor of sight to define our dilemma and our destiny. Since the curse on human beings' efforts to build their own highway to heaven, we are condemned to speak different languages, and we cannot understand one another. The gift of tongues manifested to the followers of Jesus is a sign of the lifting of this curse when God's Kingdom comes on earth, but it is only a sign. The Bible also uses the metaphor of sight: it speaks of the end of the current drought of visions, and latter-day prophets like Dr Martin Luther King Jr have claimed God's promise to the prophets of Israel. It is still possible to dream dreams and to see visions.

The academic understanding of which I speak is only a fragile human connection between another community's conviction and one's own experience. It is neither the prophet's vision nor the promised universal language. Yet there are occasional moments when the gap between Harvard classroom and distant temple is bridged, when we hear in a strange language words that we also sing:

I once was lost but now am found

Was blind, but now I see.

How much can we see? We can at least see with our mind's eye the image of the kneeling elephant, patient with our gropings, using its immense strength not to crush us, but to bear our burdens and raise us skyward. What could the Apostle Paul see? He said that he had only a childish understanding of a revelation yet to come:

For now we see in a mirror, dimly, but then we will see face to face. Now I know only in part; then I will know fully, even as I have been fully known. $^{8}$

\section{Notes}

1. The poem, entitled "The Blind Men and the Elephant, A Hindu Fable" is on pages 1877-
79 of the anthology, The Home Book of Verse: American and English, 1580-1920, Burton Egbert Stevenson, ed., New York: Henry Hold \& Co., 6th ed., 1937.

2. Kendall W. Folkert (edited by John E. Cort), Scripture and Community: Collected Essays on the Jains. Atlanta: Scholars Press, 1993.

3. See Folkert, Chapter 8, "Faith' and 'System': Darshana in the Jain Tradition", pp.113-45, and Chapter 14, "The Problem of Attitudes", pp.215-27. Ken Folkert saw the development of Jain thought as a dual process in which the sense of commonality between the Jain position and others continued to be present in the negative process of refutation, while the sense of separation, of the distinctiveness of the Jain position, was still present in the positive comparison of their position with other religious positions (p.302). This development may be understood as an application to philosophy of the primary Jain virtue of "non-injury" or non-violence, an effort to appreciate the good points of other thinkers and to do them "no harm". The belief developed, moreover, that the perfect awareness of the liberated soul must include all possible limited perspectives on reality; the Jain philosopher is anticipating that final knowledge in this more positive approach towards other philosophies.

4. J.L. Mehta, Philosophy and Religion: Essays in Interpretation. New Delhi: Indian Council of Philosophical Research with Munshiram Manoharlal Publishers, 1990, Chapter 5, "My Years at the Center for the Study of World Religions: Some Reflections", p.68.

5. This piece of oral tradition is incorporated in Vadakku Tiruvidi Pillai's lengthy commentary on Nammalvar's poem, the "Sacred utterance", in the introduction to 1.3. This commentary is known as the "Thirty-six Thousand" or Idu. I have quoted this saying in my book, The Theology of Ramanuja. New Haven: Yale University Press, 1974, p. 249.

6. Saxe, "The Blind Men and the Elephant", verse two, 1877.

7. From John Newton's Hymn, “Amazing Grace".

8. I Corinthians 13:12 NRSV. 